\title{
PEACEFUL COEXISTENCE WITH OTHERS IN ISLAM
}

\author{
Prof. Dr. Abdulxhemil Nesimi \\ Faculty of Islamic Sciences - Skopje
}

\begin{abstract}
The whole history of mankind has been a class struggle between the forces of light and darkness, good and evil, truth and wrong. Forces of good have fought to create an ideal society that is right and balanced inside and out. Unfortunately, mankind has often failed to find this balance, balance and harmony between visibility and spirituality, both inside and outside. The ideal that Islam has sought for the past 14 centuries is also a universal ideal that is to create a just society. Indeed, in this quest, the mission of the Prophet of Islam was very similar to all those prophets and wise men that came before him. Islam came as a guiding light in a dark world, a world that needed a lightning to awaken from its deep sleep. He came to the age of ignorance, where the truth was denied, when from China and Japan to the East, to Morocco and Iceland to the west, the worship of a God was replaced by a half-lump sum. At that time there were false notions of superiority and egotism based on race, color, tribe and ethnicity. Islam came to a nation boasting of the intensity of disruption and depravity in social and moral matters. Islam came historically after the fall of the Roman Empire and the 'dark ages'. In the Persian Empire there were many political disputes over power, and in the far Roman empire there were signs of decadence, and in Arabia, a land that was not supposed to reform the destiny of mankind, its citizens lacked compassion and moral values. In Arabia, in the co-operation of three major continents, Asia, Africa, and Europe, the 570th era (or the 53rd Muslim calendar) was born in Prophet Muhammad (pbuh), the prophet of Islam, a Mecca by the prominent family of the tribe Quraysh, a descendant of Babylonian Ibrahim and Hajj Egyptian. Here was revealed to the Prophet Qur'an in Arabic when he was 40 years old. Arriving in a world that had been spotted by lewdness and disintegration, Islam gave a special pattern, unrecognized throughout the history of mankind. Islam provided three basic elements, the belief in one God (in Allah), reforming oneself and society in general. Islam continued to be a religious engagement, a social, economic and political program, but above all a tool for the "constant reformation" of society.
\end{abstract}

Keywords: Islam, Quran, understanding, tolerance, harmony.

\section{Introduction}

\section{Estimates for Islam}

There is no doubt Islam is a religion that in its entirety conforms to human nature, so rightly it is called the religion of mankind. This epithet does not belong to the sake of someone's will or will, but for the sake of the legislature contained. This law naturally accepts the human mind, because it illuminates the hearts, and the faith of the scales in the depths of the soul. His concept is valid and adapts to every time and place, as it regulates issues of the human community, ensuring equality and close relationships between each other. Islam gives the possibility of trust in the Hereafter, in which reward will be rewarded according to the works of this world. Islamic religion is pervaded by the philosophy that carries and transmits values to all mankind. The values of Islam radiate the Holy Quran, the essence of which is expressed in the five pillars guiding humanity to the way of God. These are: 1) Faith in Allah 2) Forgiveness 3) Charity (Zakat) 4) Altruism (Fasting of Ramadan) 5) World Peligrination (Hajj). These and many others make Islam to be fully compatible with human nature, to be the religion that man embraces and considers as a guiding lantern in his life. Even so, man succeeds in facing the challenge of any worldly challenge.

Allah Almighty is not the Lord only for the Muslims, but for all men, and Islam is not a religion that has been presented with Muhammad (a.s), but is a continuation of the previous divine revelations, which were diverted by the unbelievers. Regarding this Allah Almighty, He commands Muhammad (pbuh) to say: "Say: I am not an 
innovator of the messengers, and I do not know what will be done with me or with you; I follow only that which is revealed to me; I am no more except a messenger who warns you clearly!" (Surah Al-Ahqaf: 9)

Islam is a divine religion for all people regardless of race, nationality, place and time and only strengthens interpersonal relationships possess many arguments from the Qur'an, sayings and deeds of the Prophet Muhammad, as well as scholars' explanations.

Above all, the value of Islam is universal, incomparable, and irreplaceable. It is divine religion but for man. Its value stems from the very essence and unique nature embodied in the progressive Islamic philosophy. Estimates about Islam come naturally not only from prominent Islamic theologians and thinkers, but also from prominent non-Islamic personalities of various fields of science, art, culture, literature, politics, and so on. The fact that over a billion Muslims, nations, races and different languages across the continent are counted in the world today, confirms that progressive growth and spread is a meaningful indication that Islam is qualitatively of incalculable value.

When mentioning the values of Islam, it is impossible not to underline the role of Prophet Muhammad (a.s) in terms of the knowledge and interpretation of the Qur'an. ${ }^{1}$

La Martin portrays so Prophet Muhammad (pbuh): "A philosopher, a speaker, a prophet, a lawyer, a warrior, a lover of ideas, a reborn renaissance of the religion of logic and of God without idols and without frescoes, the founder of the twenty kingdoms of the world and a spiritual kingdom, he is Muhammad (as). When we consider all the measures that measure the size and popularity of man, we can freely ask: Is there any greater than this?"

Tomas Karlin, English scientist in the work: "On the Heroes", 1840, writes: "Every thought on this world would be useless, if we admit that hundreds of millions of people live and die in it for something that would be untrue, because untruths can be victorious for a moment but only truth can to spark the world just as Muhammad (pbuh) sparked. The secret of the power and spread of the Islamic religion lies in its divine truth and not in the sword ${ }^{2}$ ..."

American astronomer and American historian Michael Hart in his book "One Hundred Largest" put Muhammad (a.s) in the first place and says: "The Prophet Muhammad (pbuh) was a living Quran." Separation of Quranic texts of the basic principles

The error in the meaning of Qur'anic texts and prophetic Hadith may arise from the separation of these texts from the basic principles and concepts that serve as a key that are inseparable from the subject of the search.

These principles can be summarized in the following points:

1. In origin, the purpose of the message of Islam is mercy and realization of goodness for all mankind, even for all creatures. The Exalted says: "And We have sent thee (Muhammad) solely for mercy to all creatures" (Al-Anbiya: 107)

2. The Messenger of God has explained to us that this mercy is not only for one another, but for all mankind. It is narrated that he said: "The Merciful will have mercy on the All-Merciful. Have mercy on the inhabitants of the earth so that He who is in the heavens may have mercy on you ${ }^{3}$. "From this prophetic maxim we come to understand that the order to be merciful is unlimited, not only to Muslims because they are not just the people of the earth. One of the fruits of this mercy is the greetings of good for all people and invitations for them to respond to Allah and His prophet. So, respond to the one that will give life and will realize the happiness of both worlds. Known scholar Fejsal El Meulevi raises a question saying, "Is it possible that you invite a person at a time when you hate it?! Even, he threw plans against him?! Can you invite him in this state with wisdom and good advice ${ }^{4}$ ! "In a verse of the Qur'an it is said: "Lo! Ye are the ones who love them, and they do not love you" (Ali Imran: 119)

The verse in question compares the love of a Muslim to non-Muslims and the behavior of some non-Muslim contemporaries of the Prophet (pbuh). As noted in this verse, Allah Almighty has approved this kind of love of

\footnotetext{
${ }^{1}$ KMSH, book "International Symposium - Prophet Muhammad-Mercy and Universal Love", KMSH Publications, Tirana, 2007: 109 .

${ }^{2}$ Arthur Stanley Triton, No Muslims in Islam, p. 158

${ }^{3}$ Muhammad Muhyid-Din Abdul Hamid, Transmitted in the Sunnah of Abu Dawud, Egyptian Library, Beirut, Dated, Vol.

IV, hadith, number 4941, p. 285

${ }^{4}$ FejsalMeulevi, "The Basic Concepts of Islamic Invitation in the West," taken from his website.
} 
Muslims for non-Muslims because otherwise at the end of the verse would have been said something that would explicitly prohibit their love for them and congratulations on good things and guidance in the way to them.

Likewise, this kind of love is not a love of faith and belief, but it means that those who show peace to love the good and to urge to be guided in the right path. If love for a non-Muslim would have been forbidden in itself and contrary to the principle of 'to love for God's sake and to hate only for God's sake' then Allah Almighty would not have allowed a Muslim man to marry a non-Muslim woman who was in the divine books. This is because the relationship between husband and wife must in the middle have love and respect for one another. Allah Almighty He says: "And of His signs is that for your own sake He has created from among yourselves the party, so that you may find rest in them, and in you create love and mercy. In this there are signs for those who think "(ErRrum: 21)

But in this context, we understand that the prohibition of compassion and tenderness towards non-Muslims is for those who fight against Allah (PBUH). and His Prophet, as Allah Almighty says: "There is no people who believe in Allah and the Day of Judgment, and love Him who opposes Allah and His Messenger, even if they are they (their adversaries) their parents, or their children, or their brethren, or their relatives " (al-Mujadalah: 22)

\section{Islam against racism}

Islam rejects the view that God is biased towards a particular race or tribe and that His mercy is only for a particular group.

In the chapter of al-Hujurat, verse 13 states: "O people, verily, We created you from a male and a female, and made you peoples and tribes so that you may know each other among you, and Allah is the most honest of you it is the one who has been guarded (by evil), and Allah is All-knowing and Known to Everything"

With these profound statements of the Qur'an, Islam was capable of removing century-long ethnocentric thoughts of superficial superiority and of the particular nobility of mankind. Contradicting the claims of the egocentric people that no one will enter paradise unless it is of their race and their ethnicity, for such a qualification, the Qur'an declares "It is not so (as they say), but the one who has been delivered To Allah and to the Beneficent, he has his reward with his Lord, and he is not afraid, nor does he have to be bored." (2:112)

\section{Islam preaches the unity of mankind}

The Qur'an constantly emphasizes the unity of mankind, that is, they come from the same parents: "The people were but a religion, but they were divided ..." (10:19)

The Prophet Muhammad (sas) in his farewell speech at Hajj which he held on the ninth day of the dhulhixhah in $10 \mathrm{~h}$ in the Uranah valley at Mount Arafat in Mecca, said: "All mankind comes from Adam and Eve, an Arab does not prevail over a non-arabs, nor a non-arabs has no superiority over an Arab, but a white does not prevail over a colored person, nor does a colored man have any superiority over it whites, except in devotion and good deeds. ${ }^{5 "}$

\section{There is no monopoly in the Lord's message}

The call of the Qur'an is a call to unite the faith: "He appointed to you for religion what He had appointed to Noah and what We revealed to you and what We commanded Abraham, Moses and Isa. (We beseech you) Practice the right religion and do not divide it " (42:13)

Islam presents itself as a way to co-ordinate differences between Jews and Christians. The compromise offered by Islam confirms common elements between Judaism and Christianity and accepts Musa and Jesus Christ as two of the greatest prophets of all time who were sent to guide mankind. Islam accepts the birth of Jesus without father and considers Jesus and Mary as chaste and faithful, but rejects the trinity. Accepting some of the prophets and expelling some others means not paying attention to the divine call: "Surely, those who disbelieve in Allah and His Messenger wish to distinguish between Allah and His messengers Him and say, "We believe in some and do not trust others", and they want to take a path between them. Such are the true unbelievers, and We have prepared a severe and humiliating torment for the disbelievers. (4: 150-151)

To have faith and to be a believer means to believe and put into action what you believe. In the Qur'an it is said: "It is not all good to turn your faces from the east or the west, but it is true that it is the one who believes in Allah, the Day of Judgment, the angels, the Book, the Prophets, will give to relatives, orphans, the poor, the travelers,

${ }^{5}$ Ramiq, Dr. J., "Selected Muhammad Hutbee (s.a.s.)", Published by KMSH, Tirana, 2008: 100. 
the beggars, and the release of the slaves, and the one who prays, gives zakah and those who promise and obey and the patient in poverty, illness and war flame. Such are the ones who are sincere, and such are the righteous." (2: 177)

\section{Islam hates compulsion and intolerance}

Islam does not believe in compulsion and intolerance as it becomes clear from Qur'anic verse 2: 256 "la ikraha fid-din" (which means: there is no violence in religion).

Faith is something that people have to choose for themselves. Therefore, Allah has not forced anyone to be a true believer and has given him free will to choose between alternatives. The Qur'an says: "Say: Truth is from your Lord, and whoever wills, let him believe, and whoever wills will deny" (18:29)

The aggressors are threatened with humiliation in this world and with a strong punishment in the hereafter. Churches, monasteries, synagogues and mosques, according to the Qur'an, are all places of worship: "Those who only said: 'Allah is our Lord!' And if Allah did not throw away some with others, the monasteries, the churches, the pilgrimage, and the mosques that would mention the name of Allah will be destroyed. And Allah will certainly help him who helps His way, for Allah is All-powerful and ever-triumphant. " (22:40)

Prophet Muhammad (pbuh) was constantly told that he would not feel sorry when some people refused: "Even if they belie you, they also belied those who were before them, that they were sent with clear arguments, brochures, and bright book. " (35:25)

The duty of Muhammad (SAW) was to make known the message: "If they reject us, We have not sent you to their guardians, you are only obliged to communicate" (42:48)

All these verses make it clear that there is no place for compulsion or constraint on matters of faith.

\section{Diversity in Islam}

Islam welcomes diversity in matters of faith and teaches that human diversity is a sign of God's mercy and a sign for the people of knowledge: "Among his signs is the creation of the heavens and the earth, the change of your tongues and colors ". (30:22)

The Qur'an accepts the reality of change and diversity within mankind. It gives you the impression that diversity is part of the divine plan: "Had your Lord desired, he would make people of a religion ..." (11: 118)

The Qur'an accepts the variety of laws and religious beliefs as can be understood by this verse: "For each one of you We have appointed law and program (special in action). If Allah wounded, He would make you a people, but He wanted to try you in what was given to you, so you (believers) strive for good deeds. The return of all of you is to Allah, and he will inform you of what you were opposed " (5: 48)

Because of these high notions of diversity and tolerance, Islamic civilization was pluralistic and highly tolerant with regard to various social and religious sects, which was unimaginable in other places in the middle ages.

Jewish historians testify to the fact that if it had not been for the protection and supervision of Muslim rulers, the Jews could not have survived in the Middle Ages. It was very natural for European Jews to find refuge between Muslims in North Africa and the Ottoman Empire when Christian Europe was using inquisition, massacres, and total destruction to eradicate them. Muslim rulers never interfere in the religion of their subjects. Nothing was compared to Smithfield's inquisition or fires. Consequently, a number of small Christian sects, considered as heretics by the great sects, would certainly be exterminated if left to the mercy of the great sects whose power prevailed in the Christian world, were protected and were preserved from the power of Islam. Even today, there are groups such as the Jews of Mount Yazidis and Sabaeans (Sabians) who are surviving, and their religion and culture have not been violated. Today we stand on the skeleton of religion. Many religious leaders have become predators that eat our bodies. They cause hatred and intolerance then there are secular fundamentalists who act only in their own way.

Of course, today is the debate about who is worse: a secular fundamentalist or a religious fanatic? I think both are very bad. Just as the first person must respect the religious sensitivity of others, the second one should impart the consciousness of God to help tolerate other human beings because "if only your Lord willed, they would believe what they are in land all. Will you teach people to become believers?" (Qur'an, 10: 99) 
Through the presented models it is explained how Islam established the values of tolerance and peaceful coexistence with a clear image of coexistence between religions and sects on the basis of the freedom of practicing religious rites, away from religious intolerance and distance from racial discrimination.

\section{Peaceful coexistence in Islam}

The one who analyzes the Prophet Muhammad's message (a.s) finds that Islam defended human dignity and elevated its value, and that people, both Muslim and non-Muslim, are the sons of Adam (a's). In the Holy Qur'an it is said: "Verily, We have honored the offspring of Adam, We made it possible for them to travel on the earth and in the sea, and we braved them with good things, and We esteemed them above most of the creatures which We created."(Al Isra: 70)

All enjoy their rights as human beings before God, but they are characterized by their Lord according to the level of piety, faith and morality. How Much Was Muhammad (a.s) committed to highlight this humanitarian sense in his relationships and behaviors with others!

Knowing others is the essence of Islamic faith, for we do not accept in any way to force anyone to change his religion. What we seek from the world is to read about Islam from the correct sources before making decisions about the law of Allah Almighty 6 .

Above mentioned, the question arises: did the Messenger of God focus on others only in their knowledge of or exceeded this stage and beyond?! Not only do they know them and accept them, but respect and appreciate their position.

Here's what Thomas Arnold says: "We have never heard of any attempts to force non-Muslims to accept Islam or any organized persecution aimed at the disappearance of Christianity. If the caliphs had chosen one of these plans, they would have erased Christianity from the face of the earth as easily as it was with Islam during the time of Ferdinand and Isabella in Spain; with the same method that Louis XIV pursued to make Protestantism a faith whose followers were condemned to death; or with the same ease that Jews left Britain away for more than 350 years. "

I believe that coexistence in peace and without problems between different religious beliefs makes the world safer. Therefore, religious harmony remains one of the historical, cultural and civilization values to which special attention should be paid, especially since we are living in the century of major developments and changes, this phenomenon risks becoming a myth for itself the difficult nature of the relationship between diametrically opposed cultures and religions.

Finally, we are obliged to highlight the true and bright image of the teachings of Islam, which came with compassion and love for all mankind. On the other hand, one cannot imagine a righteous life without peaceful coexistence and constructive cooperation between people of the same community and among all people. Islam in controversy calls for good ties and charity with others, despite religious differences.

\section{Conclusion}

Islam is a universal religion since its inception, and the invitations and holders of this divine message have to believe in the concept of universality of religion and should preserve the beauty of its presentation to the people.

If ignorance is a sin, little knowledge is dangerous. About 70 years ago Marmaduke Pickthall, the English poet and translator of the Qur'an, said: "If Europe knew of Islam as much as Muslims knew about Christianity at that time (during the Crusades) those crazy, adventurous, sometimes chaotic riots and heroic, but completely fanatical, known as the Crusades, would not have happened because they were based on a complete misunderstanding."

I would like to say that today the situation has improved in this information age, but it is not at the right level for opinion to bring objective data on Islam and Muslims. I hope that such inter-confessional programs will help peace-loving people, join together to fight and oppose fanaticism and intolerance, whatever their color. 

ISSN 2661-264X (Print)

The Islamic religion that propagates some individuals does not resemble the religion that Prophet Muhammad a. with it being a religion of peace, religion of security, justice, tolerance. Injustice, oppression, hostility and rape are not part of our religion.

Religion and civilizations nowadays can be united and non-divisible among people. Though different, they should convey the message of peace, understanding, and development, for their mission is not only divine, but also earthly. 
ISSN 2661-2666 (Online) International Scientific Journal Monte (ISJM) DOI: 10.33807/monte.202004627 ISSN 2661-264X (Print)

\section{References}

Ahmeti, Sheriff, Qur'an with translation into Albanian, 1998

Abdulhamijd, Muhammad Muhyid-din, Transmitted in the Sunnah of Abu Dawud, Egyptian Library, Beirut, undated, vol. IV, hadith number 4941.

El-Hufi, Ahmed Muhammad, Semahatul Islam.

KMSH, book "International Symposium-Prophet Muhammad-Mercy and Universal Love",

KMSH Publications, Tirana, 2007.

Kruja, Genti, "Albanians facing the challenges of interfaith understanding", Prizmi, Tirana, 2008.

Meulevi, Fejsal, "The Basic Concepts of Islamic Invitation in the West," taken from his website.

Mutexheli, Hanefi Abdul, El-Hurijatvelvukuk fil Islam.

Ramiq, Dr. J., "Hutbe Selected of Muhammad (s.a.s.)", Publishing KMSH, Tirana, 2008.

Triton, Arther Stanley, No Muslims in Islam.

Zuhejli, Vehbe, El-Islam vegajrulmuslimine. 